\title{
Konsep Toleransi Terhadap Orang Yang Berhutang Berdasarkan Surah Al-Baqarah 280
}

\author{
Ag. Maulana \\ Universitas Islam Negeri Sultan Syarif Kasim Riau \\ E-mail: aghe68@gmail.com, nursakinah552@gmail.com \\ Nur Sakinah ${ }^{2}$ \\ Universitas Islam Negeri Sultan Syarif Kasim Riau
}

\begin{abstract}
Abstrak
Di dalam ilmu Islam terdapat pembahasan yang menganjurkan kepada orang yang berhutang untuk memberikan tempo waktu atau toleransi jika yang memiliki hutang belum mampu melunasinya sebagaimana yang dijelaskan oleh Allah SWT dalam surah Al-Baqarah ayat 280. Adapun rumusan masalah dalam penelitian ini bagaimana konsep toleransi terhadap orang yang berhutang dalam QS. Al-Baqarah 280 dengan tujuan untukmengetahui konsep toleransi tersebut. Metode penelitian yang digunakan adalah penelitian pustaka dengan jenis pendekatan deskriptif. Buku yang menjadi sumber data adalah Kitab Tafsir Imam AlQurthubi dengan fokus ayat 280 dari surah Al-Baqarah. Hasil penelitian ini adalah ini tidak memiliki batas waktu untuk memberi tangguhan. Hanya saja ayat ini menjelaskan masa pemberian toleransi waktu untuk membayarnya sampai orang yang berhutang tersebut tidak lagi dalam keadaan kesulitan atau sudah melewati masa kesulitannya. Dan Islam menganjurkan untuk menyedekahkan hutang itu apabila yang berhutang sudah tidak mampu lagi untuk membayarkannya
\end{abstract}

Kata Kunci: Toleransi, Hutang, Tafsir Al-Baqarah 280

\begin{abstract}
In Islamic science there is a discussion that recommends people who owe debts to give time or tolerance if those who have debts have not been able to pay it off as explained by Allah SWT in Surah Al-Baqarah verse 280. The formulation of the problem in this study is how the concept of tolerance towards people who owe in QS. Al-Baqarah 280 with the aim of knowing the concept of tolerance. The research method used is library research with a descriptive approach. The book that is the source of the data is the Book of Tafsir Imam Al-Qurtubi with a focus on verse 280 of Surah Al-Baqarah. The result of this study is that it does not have a time limit for granting a deferral. It's just that this verse explains the tolerance period for paying it off until the debtor is no longer in a state of difficulty or has passed his difficult period. And Islam recommends giving alms when the debtor is no longer able to pay it
\end{abstract}

Keywords: Tolerance, Debt, Tafsir Al-Baqarah 280 


\section{Pendahuluan}

Ekonomi Syariah itu adalah suatu cabang ilmu pengetahuan yang berupaya untuk memandang, menganalisis, dan akhirnya menyelesaikan permasalahanpermasalahan ekonomi dengan cara-cara Islam, yaitu berdasarkan atas ajaran agama Islam, yaitu AlQur'an dan Sunnah Nabi shallallahu 'alaihi wasallam. Sehingga ekonomi syariah memiliki dua hal pokok yang menjadi landasan hukum sistem ekonominya yaitu Al-Qur'an dan Sunnah Rasulullah, hukum-hukum yang diambil dari kedua landasan pokok tersebut secara konsep dan prinsip adalah tetap (tidak dapat berubah kapan pun dan di mana saja).

Salah satu pembahasan di dalam ekonomi syariah ialah mengenai hutang. Hutang adalah sesuatu yang dipinjam. Pemberi hutang kepada individu ataupun badan usaha disebut kreditur, sementara individu maupun badan usaha yang meminjam disebut debitur. Dalam islam hutang dikenal dengan Qardh yang secara etimologi berasal dari kata Al-Qath'u yang berarti memotong. 
Pada saat penagihannya diantara orang yang berhutang banyak memiliki kendala dalam pembayarannya. Hal ini di karenakan ketidak mampuan terhadap melunasi hutang yang telah di sepakati saat jatuh tempo yang disebabkan kemerosotan perekonomian. Sehingga mereka mereka meminta toleransi terhadap waktu kepada debitur. Para pemberi hutang (rentenir) memanfaatkan tangguhan waktu ini untuk mencari keuntungan yang lebih seperti penambahan bunga atau uang tangguh yang membuat semakin memberatkan bagi pemilik hutang.

Di dalam ilmu Islam terdapat pembahasan yang menganjurkan kepada orang yang berhutang untuk memberikan tempo waktu atau toleransi jika yang memiliki hutang belum mampu melunasinya sebagaimana yang dijelaskan oleh Allah SWT dalam surah Al-Baqarah ayat 280 .

\section{Toleransi Dalam Islam}

Dalam kamus Bahasa Indonesia kata toleransi merupakan kata benda (nomina). Tole-ran-si mempunyai beberapa pengertian, yaitu: 1) sifat atau sikap toleran; 2) batas ukur untuk penambahan atau pengurangan yang masih diperbolehkan; 3) penyimpangan yang masih dapat diterima dalam pengukuran kerja. "Ber to-le-ran si" merupakan kata kerja (verb), jadi bertoleransi berarti bersikap toleran. Demikian juga halnya dengan kata me no le ran si. Kata ini juga merupakan kata kerja (verb) yang berarti mendiamkan: membiarkan.

Toleransi berasal dari kata "tolerare" yang berasal dari bahasa latin yang berarti dengan sabar membiarkan sesuatu. Jadi pengertian toleransi secara luas adalah suatu sikap atau perilaku manusia yang tidak menyimpang dari aturan, di mana seseorang menghargai atau menghormati setiap tindakan yang orang lain lakukan. (Bakar, 2015)

Dari beberapa pengertian di atas, baik yang dikutip dari bahasa Indonesia, maupun bahasa Latin, maka dapat disimpulkan bahwa toleransi mempunyai makna yang sangat luas yang mana bias berarti memberikan izin, membolehkan, legitimasi. lisensi, maaf, kelapangan dada, murah hati dan kedermawanan.

Toleransi dalam Islam merupakan salah satu masalah yang menarik dan penting untuk dikaji. Hal ini disebabkan oleh sebagian besar dari kalangan umat Islam yang memahami toleransi dengan menggunakan pemahaman yang salah dan tidak tepat. Misalnya, kata "toleransi" dijadikan pijakan dan landasan paham pluralisme yang menyatakan bahwa "semua agama itu benar". (Mursyid, 2016)

Toleransi dalam Islam yang dijelaskan dalam Al-Qur'an dan Tafsir adalah toleransi sebatas menghargai dan menghormat pemeluk agama lain, tidak sampai pada sinkretisme. Islam memiliki prinsip-prinsip dasar dalam toleransi ini, yakni menyatakan bahwa satusatunya agama yang benar adalah Islam, Islam adalah agama yang sempurna, dan Islam dengan tegas menyatakn bahwa selain dari Islam tidak benar, atau salah, dan sebagainya. (Yasir, 2014)

Al-Qur'an menjelaskan bahwa bagaimanapun keadaannya, kita tidak boleh 
meninggalkan toleransi. Terlepas dari kekejaman yang dilakukan oleh orang yang tidak beriman, kita jangan bertindak selain dengan keadilan dan tidak membalas dendam dengan cara yang sama kejamnya.

Standar toleransi dan keadilan dalam Islam, di mana Islam menganjurkan untuk tidak menanggapi tuduhan rendah dan hina dari kawan, karena dengan melakukan itu maka akan membuat Islam sendiri menjadi kejam. Sebaliknya, memaafkan adalah tindakan yang lebih baik dan kalaupun diharuskan untuk membalas, maka balas dengan catatan tidak melebihi batas yang telah ditimbulkan dalam Islam. Artinya, jika mereka tidak berdaya dan menyerah, maka jangan dilakukan tindakan yang berlebihan. (Bakar, 2015)

\section{Hutang Dalam Perspektif Islam Pengertian Hutang}

Dalam bahasa Arab, utang merupakan sesuatu yang berada dalam tanggung jawab orang lain. Dayn disebut juga dengan sesuatu yang harus dilunasi atau diselesaikan. Menurut Hanafiyah, dayn termasuk kepada Al- Mill. Utang dapat dikatagorikan pada Al-Mal Al-Hukmi: "sesuatu yang dimiliki oleh pemberi utang, sementara harta itu berada pada orang yang berutang." Sehingga utang negara adalah milik rakyat dan dipergunakan untuk keperluan rakyat. Selain itu, utang secara bahasa utang juga dapat bermakna memberikan pinjaman. Al-Dayn mensyaratkan jangka waktu tertentu dalam pengembalian utang, hal ini yang membedakan Al-Qardli yang tidak mensyaratkan jangka waktu tertentu dalam pengembalian utangnya, dan lebih umum dari Al-Qardh. (Huda, 2012)

Hutang secara terminologi adalah memberikan harta kepada orang yang akan memanfaatkannya dan mengembalikan ganti rugi dikemudian hari (Abdullah bin Muhammad ath-Thayyar, 2009). Sedangkan menurut Kompilasi Hukum Ekonomi Syariah, hutang adalah penyediaan dana atau tagihan antar lembaga keuangan syariah dengan pihak peminjam untuk melakukan pembayaran secara tunai atau cicilan dalam dalam jangka waktu tertentu. Definisi yang dikemukakan dalam Kompilasi Hukum Ekonomi Syariah bersifat apikatif dalam akad pinjam-meminjam antara nasabah dan Lembaga Keuangan Syariah. (Aziz \& Ramdansyah, 2016)

\section{Landasan Hukum Hutang}

Hukum Utang piutang pada asalnya diperbolehkan dalam syariat Islam. Bahkan orang yang memberikan utang atau pinjaman kepada orang lain yang sangat membutuhkan adalah hal yang disukai dan dianjurkan, karena di dalamnya terdapat pahala yang besar. Adapun dalil-dalil yang menunjukkan disyariatkannya utang piutang ialah sebagaimana berikut ini: 
Artinya : “....Dan tolong-menolonglah kamu dalam (mengerjakan) kebajikan dan takwa, dan jangan tolong-menolong dalam berbuat dosa dan pelanggaran. Dan bertakwalah kamu kepada Allah, sesungguhnya Allah amat berat siksa-Nya." (Qs. Al-Maidah : 2)

Ayat ini memerintahkan manusia agar saling tolong menolong sesama manusia, hal ini dikarenakan manusia tidak akan dapat hidup tanpa bantuan orang lain dan selalu membutuhkan orang lain. Niat tolong-menolong yang begitu baik dan ikhlas terkadang akan menimbulkan permasalahan dikemudian hari. (Aziz. et. al)

\section{Prinsip Hutang}

Utang merupakan suatu yang biasa terjadi dalam kehidupan begitu pula dalam ajaran Islam. Hal ini merupakan sunatullah yang sudah digariskan oleh Allah. Bahkan pada awal ayat surat Al-Baqarah/2: 282, disebutkan bahwa jika seorang yang beriman ingin berutang kepada pihak lain dalam jangka waktu tertentu, maka hendaklah ia mencatatnya. Hal ini menunjukan bahwa utang adalaha hal yang diperbolehkan selama memenuhi sejumlah prinsip dan etika pokok. Adapun prinsip-prinsip utang yang harus diperhatikan ialah :

a. Harus disadari bahwa utang itu merupakan alternatif terakhir ketika segala usaha untuk mendapatkan dana secara halal dan tunai mengalami kebuntuan. Ada unsur keterpaksaan di dalamnya dan kan unsur kebiasaan. Ini merupakan dua hal yang berbeda. Keterpaksaan mencerminkan semangat membangun kemandirian dan berusaha mengoptimalkan potensi yang ada semaksimal mungkin. Namun karena keterbatasan yang tidak sanggup diatasi, akhirnya terpaksa memilih jalan utang.

b. Jika terpaksa berutang, jangan berutang di luar kemampuan. Inilah yang dalam istilah syariah disebut dengan ghalabatid dayn atau terbelit utang. Ghalabatid dayn ini akan menimbulkan efek yang besar, yaitu gharir rijal atau mudah dikendalikan pihak lain. Oleh karena itu Rasulullah saw., selalu memanjatkan doa agar beliau senantiasa dilindungi dari penyakit ghalabatid dayu yang menyebabkan harga diri atau izzalı menjadi hilang (Huda, 2012).

c. Jika utang telah dilakukan, harus ada niat untuk membayarnya. Harus memiliki komitmen untuk mengembalikan utang. Memperlambat membayar utang bagi yang mampu merupakan sebuah kezaliman, sehingga diperbolehkan untuk mempermalukannya. Dalam konteks mikro, akan sangat mudah akan sangat mudah menerapkan prinsip ini. Misalnya, pengusaha yang tidak mau membayar utang boleh saja dipermalukan dengan cara menyita asetnya, dilarang berpergian ke luar negeri atau menghukum dengan hukuman yang berat. (Iska, 2012)

\section{Rukun dan Syarat Hutang}

Adapun yang menjadi syarat dan rukum yang harus dipenuhi dalam utang-piutang adalah sebagai berikut: (Mardani, 2013).

a. Sighat Yang dimaksud sighad akad adalah ijab dan kabul. Tidak ada perbedaan diantara fukaha bahwa ijab kabul itu sah dengan lafaz utang dan dengan satu lafaz yang 
menunjukan maknanya, seperti kata, "aku memberimu utang", atau "aku mengutangimu. Demikian pula Kabul sah dengan semua lafaz yang menunjukkan kerelaan, seperti "aku berutang", "aku menerima" atau "aku ridha”.

b. Akad. Akad yang dimaksud adalah akad kedua belah pihak yang melakukan teransaksi yang memberi utang dan pengutang. Adapun syarat-syarat bagi pengutang adalah merdeka, balig, berakal sehat dan pandai yang bias membedakan baik dan buruk.

c. Harta yang dihutangkan. Rukun harta yang diutangkan adalah sebagai berikut:

1) Harta yang berupa harta yang ada padanya, maksudnya harta yang satu sama lain dalam jenis yang sama tidak banyak berbeda yang mengakibatkan perbedaan nilai, seperti uang, barang-barang yang ditukar, ditimbang, ditanam dan yang dihitung.

2) Harta yang diutangkan disyaratkan berupa benda, tidak sah mengutangkan manfaat (jasa).

3) Harta yang diutangkan diketahui, yang diketahui kadarnya dan diketahui sifatnya

\section{Tambahan dalam Membayar Hutang}

Tambahan ketika membayar utang adalah tidak wajib, namun tambahan itu adalah suatu kesadaran dari seseorang yang berhutang, ia boleh menambahkan dari utang pokoknya dengan syarat tambahan tersebut tidak diucapkan diawal akad, hal ini pernah dilakukan Nabi dalam hadisnya yang artinya "Telah menceritakan kepada kami Khallad bin Yahya berkata, telah menceritakan kepada kami Mis'ar berkata, telah menceritakan kepada kami Muharib bin Ditsar dari Jabir bin 'Abdullah berkata, "Aku datang menemui Nabi saw., saat beliau berada di masjid -Mis'ar berkata, "Menurutku Jabir berkata, 'Saat waktu dluha.'Jabir bin 'Abdullah berkata, "Beliau bersabda: "Shalatlah dua rakaat." Ketika itu beliau mempunyai hutang kepadaku. Maka beliau membayarnya dan memberi tambahan kepadaku" (HR. Bukhari).

Hadis di atas menjelaskan bahwa Nabi Muhammad SAW, mengembalikan hutangnya dengan memberikan tambahan sebagai rasa ucapan syukur atau terimakasih kepada si pemberi pinjaman. Meskipun demikian, tidak boleh bagi pemberi pinjaman untuk mensyaratkan bahwa ketika nanti mengembalikan utang maka harus diberi tambahan atau kelebihan. Kalau memberi tambahan itu dilakukan dengan sukarela. Adapun kalau tambahan tersebut yang disyaratkan dalam akad, maka para ulama sepakat bahwa itu hukumnya haram. Jika memberikan tambahan yang melebihi jumlah hutangnya saat membayar hutang juga tidak diperbolehkan, hal itu bukan berarti juga diperbolehkan memberikan hadiah dan sejenisnya sebelum hutangnya sendiri di bayar, hal itu sama dengan suap yang jelas-jelas tidak dihalalkan. (As-Syaukani, 1994)

\section{Metode}

Penelitian ini disajikan dalam bentuk penelitian pustaka yang bersifat deskriptif. penelitian pustaka didefinisikan sebagai studi yang mempelajari berbagai buku referensi serta hasil penelitian sebelumnya yang sejenis yang berguna untuk mendapatkan landasan 
teori mengenai masalah yang akan diteliti dan akan menjelaskan konsep toleransi yang terkandung di dalam QS. Al-Baqarah ayat 280. Adapun buku yang akan menjadi sumber data adalah Kitab Tafsir Imam Al-Qurthubi.

\section{Hasil dan Pembahasan}

\section{Tafsir Imam Al-Qurthubi tentang QS. Al-Baqarah 280}

Al-Quran menjelaskan tentang bertoleransi terhadap orang yang berhutang dijelaskan dalam surah Al-Baqarah ayat 280 yaitu sebagai berikut : (Utsman,__)

Artinya : "Dan jika (orang yang berhutang itu) dalam kesukaran, maka berilah tangguh sampai dia berkelapangan. Dan menyedekahkan (sebagian atau semua utang) itu, lebih baik bagimu, jika kamu mengetahui".

Tabel 1. Makna ayat perkata

\begin{tabular}{|c|c|}
\hline Ayat Perkata & Artinya \\
\hline & Dan jika (orang yang berhutang itu) \\
\hline & Dalam Kesukaran/kesulitan \\
\hline & Maka berilah tangguh/tenggang waktu \\
\hline & sampai dia berkelapangan \\
\hline & Dan jika kamu menyedekahkan itu \\
\hline & Lebih baik \\
\hline & Bagimu \\
\hline & Jika kamu \\
\hline
\end{tabular}


Sumber : Data Olahan, 2021

Dalam kitab Tafsir Al-Qurthubi terdapat sembilan masalah yang terkandung di dalam surah Al-Baqarah ayat 280 ini.

Pertama. Firman Allah SWT

"Dan jika (orang berutang itu) dalam kesukaran." Setelah Allah SWT menetapkan kepada orang-orang yang melakukan riba untuk mengambil modal dasar mereka saja dan mengembalikan harta yang mereka hasilkan dari perbuatan riba, jika mereka masih memiliki harta tersebut, lalu Allah SWT menetapkan bagi orang yang merasa kesulitan dalam mengembalikannya untuk menunggu hingga keadaannya membaik.

Ayat ini diturunkan kepada masyarakat Tsaqif, ketika mereka meminta harta mereka yang dipinjamkan kepada bani Mughirah, lalu ketika bani Mughirah mengeluh bahwa keadaan mereka saat itu sedang dalam kesusahan, dan mereka juga mengatakan bahwa pada saat itu mereka tidak memiliki apa-apa untuk dibayarkan. Kemudian mereka meminta waktu hingga saat panen tiba. Lalu turunlah ayat ini,

"Dan jika (orang berutang itu) dalam kesukaran, maka berilah tangguh sampai dia berkelapangan."

Kedua: Firman Allah SWT

"Dan jika (orang berutang itu) dalam kesukaran." Dengan firman Allah SWT "Dan jika kamu bertaubat (dari pengambilan riba), maka bagimu pokok hartamu." Menunjukkan ketetapan penagihan utang dari pemilik piutang kepada orang yang berutang. Dan juga pembolehan mengambil harta orang yang berutang secara paksa. Serta menunjukkan pula bahwa ketika orang yang berutang menolak melunasi utangnya, padahal ia mampu, maka ia termasuk orang-orang yang zhalim, karena Allah SWT mengatakan

"Maka bagimu pokok hartamu." Jelas sekali bahwa para pemilik piutang memiliki hak atas penagihan harta yang dipinjamkannya, dan jika ia memiliki hak tersebut maka orang yang berutang berkewajiban untuk mengembalikan harta yang dipinjamnya.

Ketiga: Al-Mahdawi dan beberapa ulama lainnya berpendapat bahwa ayat ini sebagai pe-nasakh (ayat yang menghapus hukum) jual beli yang terdapat pada masa jahiliyah bagi orang yang kesulitan. Diriwayatkan dari Makki bahwa Nabi SAW pernah memerintahkan hal itu pada masa awal diajarkannya agama Islam.

Sedangkan jumhur ulama berpendapat bahwa firman Allah SWT 
"Dan jika (orang berutang itu) dalam kesukaran, maka berilah tangguh sampai dia berkelapangan." Ini adalah untuk seluruh manusia. Oleh karena itu, setiap orang yang sedang kesulitan ekonomi maka ia berhak untuk diberikan penangguhan. Ini adalah pendapat dari Abu Hurairah, Al Hasan, dan ulama lain secara keseluruhan.

An-Nuhas mengatakan : Pendapat yang paling baik mengenai ayat ini adalah pendapat dari Atha', Adh-Dhahak, Rabi', dan Khaitsam. Yaitu: setiap orang yang merasa kesulitan berhak untuk ditangguhkan, dalam hal riba ataupun utang. Karena pendapat ini telah menyatukan pendapat-pendapat lainnya, termasuk juga pendapat yang mengatakan bahwa ayat ini sebagai pe-nasakh yang diturunkan pada hukum riba.

Sebab, bacaan dengan harakat dhammah (pada kata ) maknanya adalah, "Jika siapapun dari kamu merasa kesulitan dalam membayar, dalam hal apapun....". Namun apabila ayat ini dikhususkan untuk riba, maka akan lebih tepat jika menggunakan harakat fathah (), yang maknanya menjadi, "Jika seseorang yang melakukan riba merasa kesulitan...".

Keempat: Barang siapa yang memiliki utang yang sangat banyak, dan para pemilik piutang menagih harta mereka, maka bagi hakim (pemimpin/ yang memutuskan perkara) untuk menanggalkan seluruh harta milik orang yang berutang tersebut untuk melunasi utangnya, dan meninggalkan apa yang menjadi kebutuhannya sehari-hari saja.

Bahkan Ibnu Nafi' meriwayatkan dari imam Malik, bahwa orang tersebut tidak boleh disisakan kecuali hanya pakaian yang dapat menutupi tubuhnya saat itu saja. Adapun pendapat yang diunggulkan dalam madzhab Maliki adalah: orang tersebut boleh ditinggali pakaian yang biasanya ia pakai sehari-hari, dan bukan pakaian yang terkesan berlebihan, namun jika pakaian yang dipakainya saat itu agak berlebihan sebaiknya tidak ditanggalkan Sedangkan mengenai pakaian istrinya atau penjualan kitab-kitab jika ia termasuk seorang yang pintar, para ulama madzhab (Maliki) berbeda pendapat mengenai pengambilan atau pembiarannya.

Kelima: Jika orang tersebut mengaku bangkrut dan tidak memiliki apa apa lagi, menurut pendapat imam Malik, dan juga Asy-Syafi'i, imam Abu Hanifah, serta ulama lainnya, maka orang tersebut harus ditahan (dipenjara) hingga terlihat jelas ketiadaannya (kemiskinannya).

Imam Malik berpendapat bahwa orang tersebut tidak harus ditahan jika ia tidak dituduh menyembunyikan hartanya dan berusaha membayar semua utangnya. Ia juga tidak harus ditahan jika kesulitannya terlihat dengan jelas, seperti yang telah kami sebutkan sebelumnya.

Keenam: Jika orang yang bangkrut tadi telah mengumpulkan uang sejumlah utangnya, kemudian uang itu hilang sebelum ia membayarkannya kepada pemilik piutang tersebut, maka orang yang bangkrut ini masih menanggung bebannya, dan piutang yang 
dimiliki pihak lain pun masih tetap ada. Akan tetapi jika uang itu telah diserahkan kepada seorang hakim (penengah), lalu sebelum diserahkan kepada pemilik piutang uang tersebut hilang dari tangannya, maka orang yang bangkrut tadi telah terlepas dari beban utangnya. Tanggung jawab telah digantikan kepada hakim atau pemilik piutang atau keduanya

Namun Muhammad bin Abdul Hakam berpendapat bahwa beban utang tersebut masih ditanggung oleh orang yang bangkrut tadi selamanya, hingga uang tersebut sampai ke tangan pemilik piutang.

Ketujuh: Makna dari kata sendiri adalah keadaan yang sulit dalam segi tidak memiliki harta. Sedangkan kata maknanya adalah: penundaan atau penangguhan. Sementara kata adalah bentuk mashdar yang bermakna dan artinya adalah kemudahan atau kelapangan.

Adapun untuk kata di-rafa'-kan karena didahului oleh kata 1 . . dan makna dari kata sendiri adalah terjadi atau merasakan. Ini adalah pendapat dari Sibawaih, Abu Ali, dan ulama bahasa lainnya. Atau boleh juga dengan menggunakan nashab, seperti yang disebutkan dalam mushhaf Ubai bin Ka'ab : j j

yang maknanya: "Jika orang yang ditagih itu merasakan kesulitan".

Kedelapan: Firman Allah SWT,

"Dan menyedekahkan (sebagian atau semua utang) itu, lebih baik bagimu." Kalimat menempati posisi mubtada', sedangkan khabarnya adalah kata

Pada firman ini Allah SWT menyarankan kepada pemilik piutang untuk bersedekah kepada orang yang berutang yang sedang dalam kesulitan, dan menjadikan sedekah itu lebih baik daripada menangguhkannya. Pendapat ini disampaikan oleh As-Suddi, Ibnu Zaid, dan Adh-Dhahak.

Kemudian Ath-Thabari juga menyampaikan makna lain dari beberapa ulama lainnya, yaitu: bersedekah kepada orang yang kaya dan orang miskin itu lebih baik bagimu. Namun tentu saja yang paling benar adalah makna yang pertama tadi, karena pada ayat ini tidak disebutkan kalimat orang kaya.

Kesembilan: Abu Ja'far Ath-Thahawi meriwayatkan, dari Buraidah bin Al Khashib, ia berkata: Rasulullah SAW pernah bersabda Yang artinya : "Barangsiapa yang menangguhkan orang yang kesulitan (dalam membayar utang) maka ia akan dilimpahkan) setiap harinya pahala bersedekah."

Adapun makna dari menangguhkan utang adalah penundaan waktu pembayaran hingga orang yang diutangi mampu untuk membayarnya. Sedangkan makna dari menghapuskan utang itu adalah membebaskan beban utang dari orang yang diutanginya.

Jelas bahawa Al-Quranul Karim menggariskan prinsip umum dalam amalan berhutang 
iaitu sekiranya penghutang menghadapi kesulitan dalam pelunasan bayaran hutangnya kepada pemiutang, ia perlu diberikan penangguhan sehingga mampu melunaskannya semula. Al-Quran tidak memperincikan apakah bentuk atau jenis kesulitan yang dihadapi oleh penghutang, malah rujukan kepada pandangan ahli tafsirpun mendapati ia hanya menyatakan dalam bentuk umum sahaja. Apa yang pasti golongan dibenarkan berhutang adalah orang yang menanggung sesuatu beban dan melalui hutang membolehkannya membayar tanggungan itu. Kedua, orang yang terbukti miskin dan hutang membolehkannya mendapatkan sumber untuk meneruskan kehidupan; dan ketiga adalah orang ditimpa bencana sehingga harta bendanya musnah dan hutang membolehkannya mendapatkan sumber untuk memulihkan kehidupan seperti sedia kala.

\section{Konsep Toleransi dalam QS. Al-Baqarah 280}

Berdasarkan penjelasan di atas bahwasanya Islam itu sangat mudah dan penuh dengan toleransi disetiap amalannya. Begitu pula dengan orang yang berhutang yang memiliki kesulitan dalam membayarnya. Sehingga Islam memberikan petunjuk kepada umatnya bahwasanya sifat bertoleransi terhadap orang yang berhutang itu sangat dianjurkan dengan niat tolong menolong sesama muslim.

Sifat tolong menolong inilah yang membuat tidak bolehnya atau diharamkannya untuk memanfaatkan makna penangguhan ini dengan menambahkan tingkat bunga yang bersifat riba seperti yang di praktikkan pada rentenir saat ini. Tambahan dalam pemberian hutang itu termasuk riba jikalau ditetapkan pada saat akad diawal dan keinginan secara pribadi dari sang pemberi hutang. Lain hal dengan keikhlasan dari sang pemilik hutang yang memberikan saat pelunasan dari hutangnya dengan makna sebagai tanda terimakasih untuk sang pemberi hutang, hal ini dimaknai dengan sebagai hadiah dan pemberi hutang pun halal untuk menggunakannya.

Konsep toleransi yang terkandung dalam surah Al-Baqarah ayat 280 ini tidak memiliki limit atau batas waktu untuk memberi tangguh. Hanya saja ayat ini menjelaskan masa pemberian toleransi waktu untuk membayarnya sampai orang yang berhutang tersebut tidak lagi dalam keadaan kesulitan atau sudah melewati masa kesulitannya. Tetapi apabila orang yang berhutang itu sudah merasa mampu untuk membayarnya dan mereka tidak mau membayar kewajiban hutangnya maka kita selaku pemberi hutang berhak untuk mengambil barang berharganya dengan paksa, dan ini di anjurkan oleh Allah SWT agar tidak memiliki beban hutang di akhirat kelak.

Allah SWT juga memberikan solusi terakhir kepada orang yang memberi hutang apabila orang yang berhutang itu tidak mampu lagi untuk membayarkan hutangnya tersebut dengan memutuskan beban hutangnya sebagian atau sepenuhnya dari jumlah hutang tersebut. Memutuskan beban hutang yang dimaksud adalah mengikhlaskan hutang tersebut dan tidak dituntut kembali hak membayarnya atau disebut dengan sedekah. Dengan menyedekahkan harta yang dihutangkan maka Allah SWT yang sangat menjaminkan kehidupan kita yang lebih baik, karena sedekah itu sangat besar pahalanya. 
Praktek penangguhan bayaran hutang ini telahpun diterima secara meluas amalannya oleh masyarakat Islam. Tidak hanya secara personalia bahkan termasuk juga di dalam sektor keuangan dan perbankan syariah. Adapun toleransi di dalam dunia perbankan syariah terhadap nasabah yang melakukan pembiayaan bermasalah adalah sebagai berikut :

a. Dengan cara merestrukturisasi Pembiayaan terhadap nasabah yang mengalami penurunan kemampuan membayar namun dinilai masih memiliki prospek usaha dan mempunyai kemampuan untuk membayar setelah restrukturisasi. Pelaksanaan Restrukturisasi Pembiayaan pada Bank, harus tetap memenuhi prinsip syariah disamping mengacu kepada prinsip kehati-hatian yang bersifat universal yang berlaku pada industri perbankan. Selain itu, aspek kebutuhan dan kesesuaian dengan perkembangan industri perbankan syariah menjadi pertimbangan dalam penyempurnaan ketentuan mengenai Restrukturisasi Pembiayaan di Bank Syariah dan Unit Usaha Syariah.

b. Penyelesaian melalui jaminan dilakukan oleh bank syariah bilamana berdasarkan evaluasi ulang pembiayaan, prospek usaha nasabah tidak ada, dan atau nasabah tidak kooperatif untuk menyelesaikan pembiayaan atau upaya penyelamatan dengan upaya restrukturisasi tidak membawa hasil melancarkan kembali pembiayaantersebut. Maka upaya penyelesaian pembiayaan bermasalah dengan cara eksekusi jaminan akan dilakukan oleh bank syariah.

c. Penyelesaian lewat Badan Arbitrase Syariah Nasional, bilamana jika salah satu pihak tidak menunaikan kewajibannya atau terjadi perselisihan diantara kedua belah pihak dan tidak tercapai kesepakatan melalui musyawarah, maka penyelesainya melalui Badan Arbitrase Syariah Nasional (BASYARNAS) dengan kewenangannya.

d. Penyelesaian lewat litigasi akan ditempuh oleh bank bilamana nasabah tidak beritkad baik yaitu tidak menunjukkan kemauan untuk memenuhi kewajibannya sedangkan nasabah sebenarnya masih mempunyai harta kekayaan lain yang tidak dikuasai oleh bank atau sengaja disembunyikan atau mempunyai sumber-sumber lain untuk menyelesaikan kredit macetnya.

e. Hapus Buku dan Hapus Tagih. Hapus buku adalah tindakan administratif bank untuk menghapus buku pembiayaan yang memiliki kualitas macet dari neraca sebesar kewajiban nasabah tanpa menghapus hak tagih bank kepada nasabah. Hapus tagih adalah tindakan bank menghapus kewajiban nasabah yang tidak dapat diselesaikan, dalam arti kewajiban nasabah dihapuskan tidak tertagih kembali. Hapus buku dan hapus tagih hanya dapat dilakukan terhadap pembiayaan yang memiliki kualitas macet. Hal ini sesuai dalam QS. Al-Baqarah ayat 270 yang menyedakahkan sebagian atau sepenuhnya dari hutang yang dimiliki karena faktor ketidak mampuannya dalam melunasi kewajibannya

\section{Simpulan}


Berdasarkan kepada perbincangan di atas, Islam mengharuskan umatnya untuk berhutang atas keperluan tertentu dan terdesak. Namun perubahan zaman menyaksikan bahawa penghutang hari ini tidak hanya melibatkan golongan miskin tetapi juga golongan elit dan kelas menengah. Islam juga mengharuskan pemiutang agar memberikan ruang masa kepada penghutang yang berada dalam kesulitan untuk melunaskan hutangnya dan yang paling baik ialah beliau dengan rela hati melupuskan sebahagian hutang atau semua baki hutang penghutang untuk mendapatkan ganjaran yang lebih baik di sisi Allah SWT.

Referensi(Cambria, 12pt)

Abdullah, 2009, Ensiklopedi fiqh Muamalah Dalam Pandangan 4 mazhab, Maktabah al-Hanif, Yogyakarta.

Asy-Syaukani, Muhammad, 1994, Nailul Autar, terj. Adib Bisri Mustafa, Asy Syifa, Semarang

Aziz, A., \& Ramdansyah, R. (2016). Esensi Utang dalam Konsep Ekonomi Islam. BISNIS: Jurnal Bisnis dan Manajemen Islam, 4(1), 124-135.

Bakar, A. (2016). Konsep toleransi dan kebebasan beragama. TOLERANSI: Media Ilmiah Komunikasi Umat Beragama, 7(2), 123-131.

Huda, Nurul, 2012, Keuangan Publik Islami Pendekatan Teoritis dan Sejarah, Kencana, Jakarta

Iska, Sukri, 2012, Sistem Perbankan Syariah di Indonesia dalam Perspektif Fikih Ekonomi, Cetakan Pertama, Fajar Media Press, Yogyakarta

Kolistiawan, B. (2014). Tinjauan Syariah Tentang Pembiayaan Bermasalah Di Perbankan Syariah. State Islamic Institute of Tulungagung.

Mardani, 2013, Fiqh Ekonomi Syariah, Kencana, Jakarta

Mursyid, S. (2018). Konsep Toleransi (Al-Samahah) Antar Umat Beragama Perspektif Islam. Aqlam: Journal of Islam and Plurality, 1(2).

Utsman, Mahmud Hamid, 2009, Tafsir Al-Qurthubi Jilid 3, Pustaka Azam, Jakarta

Yasir, M. (2014). Makna Toleransi dalam Al-Qur'an. Jurnal Ushuluddin, 22(2), 170-180. 